Uniwersytet Szczeciński

martyna@gibka.pl

\title{
FUNKCJE NAZW PARKÓW LINOWYCH W POLSCE
}

Słow a tematyczne: onomastyka, mikrotoponimia, funkcje nazw własnych

\section{WSTĘP}

Parki linowe to obiekty sportowo-rekreacyjne umożliwiające spędzenie czasu na drzewach i pomiędzy nimi, od kilku do kilkunastu metrów nad ziemią. Dają szansę sprawdzenia się, wykazania odwagi, opanowania, równowagi i kondycji w trakcie wspinaczki. Większość parków oferuje kilka tras o różnych poziomach trudności i na różnych wysokościach. Każda trasa składa się z około kilkunastu przeszkód, takich jak: most birmański, skok Tarzana, rozrywające belki, trapezy, skok na siatkę czy zjazdy na linie. Ze względu na położenie — głównie w miastach lub na ich obrzeżach — parki linowe umożliwiają wspinaczkę oraz zabawę na wysokości bez konieczności dalekich podróży i przygotowań. Co więcej, oferując specjalnie zabezpieczone trasy dla najmłodszych, stanowią cel popołudniowych i weekendowych spacerów dla całych rodzin.

Pomimo rosnącej popularności oraz liczby parków linowych w Polsce ich nazwy nie zostały dotąd zbadane. Jednoznaczna klasyfikacja tych onimów nie jest łatwa, można jednak pokusić się o włączenie ich do kategorii mikrotoponimów, chrematonimów lub neotoponimów.

Celem niniejszej pracy będzie analiza funkcjonalna 227 nazw parków linowych, a w szczególności rozstrzygnięcie, jakie funkcje sekundarne pełnią badane jednostki onimiczne oraz które $\mathrm{z}$ nich są dominujące. Elementem dość często wpisywanym przez twórców w strukturę nazwy jest wyrażenie park linowy. Nie jest to jednak element onimiczny, a określenie identyfikujące (rodzajowe, utożsamiające, wskazujące na typ obiektu, a nie na jego specyficzność, jednostkowość). Onomasta badający nazwy parków linowych mógłby więc oddzielić to wyrażenie od analizowanych onimów. Jak zostanie wykazane jednak w dalszej części pracy, skutkiem takiej decyzji byłoby wykluczenie ze studium funkcji sekundarnej pełnionej przez część omawianych denominacji. 


\section{FUNKCJE NAZW PARKÓW LINOWYCH}

Materiał badawczy zebrany do analizy pochodzi z portalu internetowego http://polskieparkilinowe.pl/ (dostęp 29 VIII 2016). Ponieważ tradycyjne ujęcia, takie jak dwustopniowa, strukturalno-gramatyczna klasyfikacja nazw S. Rosponda czy genetyczno-semantyczna klasyfikacja W. Taszyckiego, nie dostarczyły narzędzi umożliwiających zbadanie funkcji nazw własnych parków linowych, do analizy wykorzystano metodologię zaproponowaną przez M. Rutkowskiego (2001) w studium mikrotoponimii przestrzeni wspinaczkowej. Przyjmuje się za nim definicję funkcji oraz metodę ich wyodrębniania, lecz zestaw ról, jakie odgrywają, zaproponowany przez M. Rutkowskiego został w niniejszym artykule — ze względu na różnice $\mathrm{w}$ analizowanym materiale - zmodyfikowany.

Funkcja nazwy własnej parku linowego jest rozumiana jako rola, jaką nomen proprium odgrywa w relacji do danego elementu aktu nominacyjnego (Rutkowski 2001: 40-44): „Takie zorientowanie perspektywy umożliwi wychwycenie tych funkcji nazw, które były istotne w samym momencie ich powstawania" (tamże: 41). Model aktu nominacji, na którym oparto analizę, wygląda następująco:

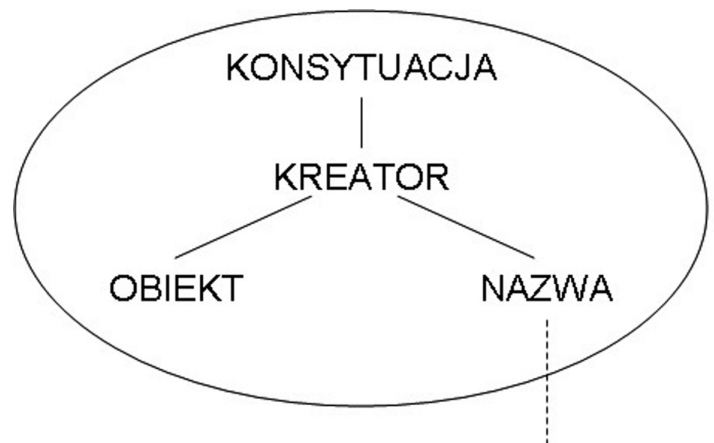

UŻYTKOWNIK

Źródło: Rutkowski 2001: 43

Centralną pozycję w procesie nazewniczym zajmuje kreator (osoba nazywająca obiekt — podmiot, którego ranga w połączeniu ze społeczną potrzebą komunikacyjną sprawia, że obiekt musi zostać nazwany). Nazwą jest znak językowy przypisany obiektowi, a zespół okoliczności towarzyszący wyodrębnieniu obiektu i nazwaniu ujęty został w konsytuacji. Wyłączony poza „obręb konsytuacji aktu nominacyjnego" użytkownik to z kolei grupa osób, które używają (będą używać) danej nazwy (tamże: 42-43).

Rozpatrując funkcje nazw parków linowych na tle powyższego modelu aktu nominacji, wyróżnić należy pięć relacji, w które może wchodzić onim: nazwa-obiekt; 
nazwa-kreator; nazwa-nazwa; nazwa-konsytuacja oraz nazwa-użytkownik. W każdej z tych relacji jednostka onimiczna może pełnić funkcje sekundarne, w pierwszej wszystkie denominacje pełnią natomiast funkcję prymarną — identyfikująco-dyferencyjną, którąjest — jak pisze M. Rutkowski — ,,wskazywanie na jeden, konkretny obiekt i jednoczesne odróżnianie go od innych, podobnych obiektów" (tamże: 38).

\subsection{Relacja nazwa-obiekt}

W relacji do obiektu nazwa własna może pełnić funkcję deskrypcyjną. Do jednostek deskrypcyjnych zaliczamy — za M. Rutkowskim — te, ,w których zawarty jest opis (charakterystyka) denotatu poprzez wskazanie pewnych szczególnych jego cech. [...] Dzięki niej [funkcji deskrypcyjnej] odbiorca jest informowany o istotnych, charakterystycznych cechach obiektu, zawartych w nazwie” (tamże: 46). „Motyw semantyczny nazw deskrypcyjnych może pochodzić od cech [...] inherentnych obiektu”, zatem nazwy pełniące taką funkcję „opisują obiekt [...] ze względu na jego charakterystyczne cechy fizyczne" (tamże: 47). Wskazywana cecha denotatu, leżąca u podstaw onimu, może być — jak to określa M. Rutkowski — „obecna w strukturze nazwy" bezpośrednio lub też metaforycznie (tamże: 51).

W zbadanym materiale funkcję deskrypcyjną pełnią 83 nazwy parków linowych. Dzieląc jednostki deskrypcyjne pod względem sposobu wskazywania cechy, do grupy onimów opisujących denotat bezpośrednio możemy zaliczyć nazwy oparte na pojęciach:

- adrenaliny: Adrenalina Park, Adrenalina, AdrenaLinaPark Podlesice, AdrenaLinaPark Podzamcze, Lina Adrena, Power Park (ang. power 'moc, siła');

- przygody (ang. adventure): ADVENTURE — Park Przygody Gubatówka, Afor Adventure Park, Fabryka Przygody, PARK LINOWY „,Adventure-sky” (ang. sky 'niebo' - park oferuje trasy na wysokości do $11 \mathrm{~m})$, Park Linowy Las Przygód, Park Linowy Leśna Przygoda, Park Przygody Nad Pilica, Przygoda Park, Sparta Adwenture Park;

- zabawy: Fun Park (ang. fun 'zabawa'), FUN-Linopark, FunForce, Park Linowy , 4FUN”, Park Linowy Góra Harców, Park Linowy Radocha, Park Rekreacji Zoom Natury, Park Rozrywki Knieja;

- wrażeń: AndersLand Fabryka Wrażeń (wrażenia gwarantowane), Kraina Wrażeń, Mountain Emotion (ang. mountain 'góra', emotion 'emocja');

— aktywności: Gwarek Centrum Aktywnego Wypoczynku;

a także nazwy wskazujące:

- umiejscowienie: Czarodziejska Góra - Centrum Sportów Górskich, High-Position (ang. high-position 'wysoka pozycja'), Kamienna Góra, Leśny Park Linowy, Leśny Tabor, Murzasichle - Stary Bór, Na Wydmie, Park Linowy „Leśny Raj”, Rodzinny Park Rozrywki ,,Trzy Wzgórza” (park położony na wzniesieniach), Piaski-Szczygliczka (park znajduje się przy plaży), Wyspa Przygody Opatowicka; 
- intensywność/poziom trudności tras: Park Linowy Chrobry (chrobry 'dzielny', bojaźliwi na trasy tego parku nie wejda), Park Linowy Hardcore (ang. hardcore 'bardzo intensywny'), Xtremepark, Wypasiona Dolina („wypasione”, czyli „odlotowe" trasy), Inowroctaw Centrum Extreme, Cascader Park, Wake Park Solina (wysokość $20 \mathrm{~m}$ i prędkość zjazdu $60 \mathrm{~km} / \mathrm{h}$ rozbudzą każdego — por. ang. wake 'budzić') oraz Sparta Adwenture Park;

— wielkość/wygląd parku: Park Linowy Stolëm (najwyższy park na Kaszubach; por. kasz. stolëm 'gigant' (Sychta 1972: 165), Pod Palmami (słupy, na których zamontowane są przeszkody, zakończone są liśćmi palmowymi), Podniebny Cyrk (park oferuje aż siedem tras na dużej wysokości), Rodzinny Park Linowy (trasy parku są tak dobrane, że umożliwiają zabawę całej rodzinie), Tyrolkowo (park złożony wyłącznie z tyrolek, czyli zjazdów na linach);

- wykonywane czynności: Jumpy Park Malborkstones (ang. jumpy 'nierówny; zmienny; nerwowy; skoczny', por. ang. jump 'skakać'), Jumpy Park, dwa parki linowe o nazwie Linoskoczek, Mamruch (nazwa deskrypcyjna, jeśli odczytamy ją jako 'mam ruch'), Park Linowy Odkrywców (odkrywamy trasy oraz swoje możliwości i lęki), Park Linowy Revolta (rewolta, „sprzeciw wobec obowiązujących norm"1 - tutaj wobec prawom grawitacji i chodzenia po ziemi).

Wśród nazw opisujących denotat metaforycznie znalazły się: cztery parki linowe o nazwie Gibon (por. gibon: „wąskonosa małpa człekokształtna o bardzo długich kończynach przednich, bez ogona"2, Leśny Kot, dwa parki linowe o nazwie Tarzan (korzystających z tras można porównać do Tarzana, czyli „,fikcyjnej postaci mężczyzny wychowanego w dżungli” (Rutkowski 2012: 115)), kolejne dwa o nazwie Tarzania (miejsce dla Tarzanów), pięć o nazwie TarzanPark, Wiewióra oraz Veni Vici (z reklamy: „Filozofia naszej firmy sięga korzeniami do łacińskiej maksymy Veni-Vidi-Vici (Przybyłem. Zobaczyłem. Zwyciężyłem). Poprzez proponowane rozrywki sportowe chcemy dać każdemu możliwość zmierzenia się z samym sobą. Proste stwierdzenie «Udało mi się. Dałam, dałem radę» przynosi ogromnie dużo satysfakcji bez względu na wiek czy kondycję fizyczną. Przyjemność stanowi już samo pokonywanie przeszkód, uczenie się koncentracji, opanowania, czyli samopoznanie"3).

Ponadto dwie nazwy łączą w sobie deskrypcję bezpośrednią i metaforyczną: Matpi Gaj (metaforycznie od aktywności charakteryzującej malpy do wielkiej sprawności człowieka i bezpośrednio: od umiejscowienia obiektu wśród drzew — gaj), Małpi Jar (metaforycznie od aktywności 'ts.' oraz bezpośrednio od zlokalizowania parku w pobliżu małp — park znajduje się na terenie zoo, nie znajduje się jednak w jarze).

Co więcej, deskrypcje z zasobów zbadanego materiału wykraczają poza opis bezpośredni i metaforyczny. Cztery parki linowe o nazwie $J u-H u u$ opisują denotat metonimicznie (,ju-huu” — okrzyk przy zjazdach tyrolkami).

\footnotetext{
${ }^{1} \mathrm{http}: / /$ sjp.pwn.pl/slowniki/rewolta.html (dostęp 7 IX 2016).

${ }^{2}$ https://sjp.pwn.pl/szukaj/gibon.html (dostęp 9 IX 2017).

${ }^{3}$ http://www.veni-vici.com.pl/dlaczego.php (dostęp 8 IX 2016).
} 


\subsection{Relacja nazwa-kreator}

\section{Rutkowski pisze:}

[...] nazwa pełni wobec kreatora funkcję ekspresywną, co oznacza, że odzwierciedla stosunek kreatora do otaczającej go rzeczywistości, a także uzewnętrznia cechy jego osobowości. Za pośrednictwem nazw ekspresywnych odbiorca uzyskuje określoną charakterystykę nadawcy (twórcy nazw): [...] ekspresja w tym rozumieniu polega najczęściej na ogólnokulturowym określeniu kreatorów, a równocześnie podkreśleniu ich pomysłowości, kreatywności językowej, poczucia humoru. Niekiedy też nazwy zdradzają stany emocjonalne [kreatorów] (2001: 85).

Podobnie jak w analizie M. Rutkowskiego, tak i tu ,do grupy nazw ekspresywnych włączono wszystkie jednostki, które odsłaniają cechy ich twórców (zalicza się tu przeniesione tytuły ${ }^{4}[\ldots]$, nazwy zawierające elementy leksykalne nacechowane stylistycznie, środowiskowo i pochodzące z innych języków), a także odzwierciedlające poczucie humoru nazwy żartobliwe — z wyjątkiem tych, które skupiają uwagę odbiorcy na strukturze, formie językowej, specyficznym uporządkowaniu formalnym. Te ostatnie zalicza się do klasy nazw o funkcji poetyckiej” (tamże: 86).

W zbadanym materiale znalazło się 16 propriów pełniących funkcję ekspresywną. Nazwa Lina Adrena ujawnia pomysłowość kreatora (: adrenalina i lina 'sznur'), a Sherwood nawiązuje do opowieści o Robin Hoodzie, postaci fikcyjnej przebywającej w lesie Sherwood. Trzy jednostki onimiczne — Park Linowy „, Galadusys”, Park Linowy Stolëm oraz Veni Vici — wskazują na znaczenie lub zainteresowanie kreatorów językiem litewskim, kaszubskim i łacińskim. Pozostałych 11 nazw przejawia cechę, którą M. Rutkowski nazwał ekspresywnym dowcipem:

Źródłem ekspresji bywa dowcipne skojarzenie apelatywnego znaczenia leksemów, organizujących strukturę danej jednostki onimicznej z typowymi cechami jej denotatu. [...] komizm budowany jest najczęściej na zestawieniu semantyki nazwy (ściślej: jej wyjściowej struktury apelatywnej — czyli znaczenia etymologicznego, leksykalnego nazwy) ze specyfiką, nietypowością (tamże: 92).

Tego typu dowcip pojawia się w nazwach czterech parków linowych: Gibon (por. gibać się — kołysać się na przeszkodach lub po spadnięciu z nich — nie da się przejść żadnej trasy w parku linowym, nie kołysząc się) oraz w nazwie Park Rekreacji Zoom Natury (ang. zoom 'zbliżenie' — czasami może być większe niż pożądane, np. jeżeli uczestnik zabawy odkryje, że ma lęk wysokości, o którym nie wiedział, i zacznie kurczowo obejmować najbliższe drzewo).

\subsection{Relacja nazwa-nazwa}

Jedyną funkcją pełnioną przez denominacje w tej relacji jest funkcja poetycka, którą „nazwy własne pełnią wtedy, gdy nie odsyłają do innych elementów aktu nominacyjnego, zatrzymując uwagę odbiorcy na swej strukturze [...]. Funkcję tę pełnią te

\footnotetext{
${ }^{4}$ A także inne elementy dzieł literackich.
} 
jednostki onimiczne, które posiadają szczególnego rodzaju wewnętrzne zorganizowanie, zwracające w pierwszym rzędzie uwagę na formę językową, «[...] na siebie, swą postać, na to, jak jest zbudowany [komunikat językowy — M. R.]» (Handke 1993: 135)" — stwierdza Rutkowski (2001: 100-101). Z pięciu wyróżnionych przez niego sposobów kreowania propriów pełniących funkcję poetycką ${ }^{5}$ wśród nazw parków linowych odnaleźć można trzy. „Pierwszym sposobem specjalnego wewnętrznego zorganizowania [...] jest wykorzystanie rymu jako zabiegu determinującego ich strukturę" (tamże: 101). Tak zostało utworzone tylko jedno nomen proprium Barbarkowy Park Linowy.

Drugą grupe poetyckich denominacji tworzą propria będące transformacjami słów oraz powiedzeń. W zbadanym materiale pojawiły się dwie takie jednostki: Lina Adrena oraz Veni Vici.

Ostatnią, najliczniejszą grupę relacji: nazwa-nazwa stanowią propria, które przyciagają „uwagę odbiorcy nietypową postacią ortograficzną lub graficzną” (tamże: 104). Są to: ABlandia - Krościenko, ABlandia - Rytro, AdrenaLinaPark Podlesie, AdrenaLinaPark Podzamcze, Bartbo Park Rozrywki Aktywnej, Expedycja, GuGu Park linowy, Park Linowy „4FUN”, Park Linowy Kanyon, Park Linowy Rewolta oraz Xtremepark.

\subsection{Relacja nazwa-konsytuacja}

W relacji nazw do konsytuacji w tym artykule zostają — za M. Rutkowskim przejęte: funkcja pamiątkowa oraz aluzyjna. Ponadto wyróżniona zostaje funkcja lokalizacyjna, którą badacz włączył w obręb funkcji deskrypcyjnej ze względu na inne niż w niniejszej pracy rozumienie przez niego „lokalizacji”. M. Rutkowski definiuje nazwy lokalizujące (stanowiące u niego jedną z grup nazw deskrypcyjnych) jako wskazujące na „położenie obiektu względem innych, jego orientację geograficzną lub kierunek przebiegu" (2001: 47). Takie pojmowanie lokalizacji wpisuje się w relację nazwa-obiekt i jest szeroko reprezentowane wśród mikrotoponimów przestrzeni wspinaczkowej, którą M. Rutkowski się zajmował, nie znajduje jednak zastosowania w badaniach nazw parków linowych, gdzie lokalizacja zachodzi nie pomiędzy dwoma obiektami, lecz obiektem a konsytuacją. Funkcję lokalizacyjną będą tu zatem pełniły nazwy określające położenie ich denotatów względem fizycznego otoczenia kreatora nazwy (tu: Polska).

Tak zdefiniowana funkcja lokalizacyjna jest najczęściej pełniona przez zbadane jednostki onimiczne. Wśród nazw lokalizacyjnych najwięcej odsyła do miejscowości, w/przy której znajduje się denotat: ABlandia - Krościenko, ABlandia Rytro, AdrenaLinaPark Podlesie, AdrenaLinaPark Podzamcze, Base Camp Istebna, Battowski Park Linowy Skarbka, Bielawa, Ciechocinek, Człuchów OSiR, Ełcki Park Linowy, Geo-Park Glinka, Goluchowski Park Linowy, GRAND Chotowa,

\footnotetext{
${ }^{5}$ Zob. Rutkowski 2001: 101-104.
} 
Inowrocław Centrum Extreme, Jasło, Jumpy Park Malborkstones, Kamienna Góra, Kielecki Park Linowy, Kleczew, Koszalin Awana, Kołobrzeski Park Linowy, Krakowski Park Linowy, Krynicki Park Linowy, Krzeszów, Krzywa, LKJ Solec w Bieruniu, MOSiR Zgierz, Murzasichle - Stary Bór, Okuninka, Park Jeroniki, Park Linowy Doktorce, Park Linowy Drozdówka, Park Linowy Górzno, Park Linowy Jachranka, Park Linowy Józefów, Park Linowy Kamińsk, Park Linowy Kazimierz, Park Linowy Kletno, Park Linowy Krasnobród, Park Linowy Malutkie Resort, Park Linowy Milówka, Park Linowy na Ranczu Boguszewiec, Park Linowy Piła-Młyn, Park Linowy Podjanowszyzna, Park Linowy Solina, Park Linowy Spychowo, Park Linowy w Iwoniczu Zdroju, Park Linowy w Kryspinowie, Park Linowy w Mielniku, Park Linowy w Nakorach, Park Linowy w Niemodlinie, Park Linowy w Spale, Park Linowy Warszawa, Park Linowy WOSiR Szelment, Park Linowy Lagów Lubuski, Park Linowy Żywiec, Park Radawa, Podstolice Ski \& Adventure, Pomiechówek, Rabczański Park Linowy, Park Linowy Białka Tatrzańska, Rudnica Park, Sabat Krajno, Sieradz, Starogardzki Park Linowy, Szczytna, Szklarska Poręba Trollandia, Świętochłowice - Skałka, Wake Park Solina, Wawrzkowizna, Wierchomla, Wólka Nadbużna, Włocławski Park Linowy oraz Zamość.

W zbiorze nazw lokalizacyjnych znalazły się również onimy odsyłające do innych obiektów:

— gór: Czarny Groń, Park Linowy Dębowiec, Park Linowy Wieżyca, Piękna Góra Rudziewicz;

— rzek: Park Przygody Nad [sic!] Pilica;

— jezior: Park Linowy „, Galadusys”, Park Linowy Paprocany, Park Linowy Tajty, Park Przygody Balaton;

— zalewów: Zalew Zembrzycki;

— wysp: Wyspa Przygody Opatowiecka;

— wzniesień: ADVENTURE — Park Przygody Gubałówka;

— osiedli: Arturówek;

- dzielnic: Barbarkowy Park Linowy, Kolibki Adventure Park, Park Linowy Bielany, Park Linowy Ursus, Port Brzeźno;

— mórz: Park Linowy Nad [sic!] Battykiem, Park Linowy Polskie Morze.

Ponadto w zbadanym materiale znalazły się cztery nazwy parków linowych, które również lokalizują denotat, lecz wykraczają poza zaproponowane wyżej klasy. Park Linowy Mierzeja określa położenie denotatu, lecz niejednoznacznie, gdyż w Polsce znajduje się więcej niż jedna mierzeja. Podobnie nazwa Ślaski Park Linowy wskazuje region, lecz nie dokładną lokalizację parku. Nazwy Park Linowy Stolëm oraz Pyrland ${ }^{6}$ Park określają natomiast położenie denotatów za pomocą języka i gwary, z której pochodzą (Kaszuby oraz Wielkopolska).

${ }^{6}$ Leksem Pyrland to derywat od Pyrlandia (gw. nazwa Wielkopolski), a denominacja ta pochodzi od apelatywu pyra ‘ziemniak' (Gruchmanowa, Walczak (red.) 1997: 347). 
Kolejną funkcję - pamiątkową - nazwa pełni względem konsytuacji, ,jeśli w sposób bezpośredni upamiętnia któryś z [...] jej elementów składowych. Możliwość upamiętniania w nazwach własnych postaci i różnego typu zjawisk z realnej rzeczywistości wiąże się z naturą i rangą jednostek onimicznych — postrzeganych jako znaki językowe szczególnego rodzaju, odznaczające się dużą trwałością (stabilnością) i szerokim obiegiem komunikacyjnym" zauważa Rutkowski (2001: 59).

Nazwy parków linowych w Polsce najczęściej upamiętniają nazwę większego kompleksu, np. hotelu: Park Linowy Tajty, Park Linowy „,Magellan”, Park linowy Hanza Pałac, Park Linowy Faltom, Niedźwiadek, Kocierz, Hotel Remes, GeoPark Linowy (na terenie hotelu Geovita), GRAND Chotowa. Pozostałych 12 pamiątkowych onimów odnosi się do nazw innego rodzaju ośrodków, przy których znajdują się parki: Izydory (na terenie obiektu Dworek Izydory), Park Linowy Agroturystyka „Osada Babia Góra” (na terenie gospodarstwa agroturystycznego „Osada Babia Góra"), Park Linowy Kapielisko Chorwacja (na terenie Kapieliska Chorwacja), Park Linowy Klub Piknikowy (na terenie Klubu Piknikowego), Park Linowy Malutkie Resort (na terenie kompleksu rekreacyjno-wypoczynkowego Malutkie Resort), Park Linowy Myślęcinek (na terenie Leśnego Parku Kultury i Wypoczynku w Bydgoszczy, również o nazwie Myślęcinek), Park Linowy na Ranczu Boguszewiec, Park Linowy Piła-Młyn (na terenie ośrodka PilaMlyn), Park Linowy Rokita (na terenie Kompleksu Hotelowo-Sportowego Rokita), Piaski-Szczygliczka (na terenie Parku Przygód Piaski Szczygliczka), Pod Palmami (na terenie Centrum Zdrowia i Rekreacji Park Pod Palmami), Piękna Góra Rudziewicz (na terenie obiektu Zajazd Piękna Góra Rudziewicz). Ta ostatnia nazwa upamiętnia również nazwisko właściciela parku.

Ostatnią funkcją, jaką niektóre nazwy parków linowych pełnią w relacji do konsytuacji, jest funkcja aluzyjna. Podobnie jak w rozprawie M. Rutkowskiego, tak i w tym artykule ,pojęcia aluzja nie traktuje się w kategoriach terminu teoretycznoliterackiego, ale używa w znaczeniu zbliżonym do potocznego: «wzmianka, napomknienie, mające wywołać określone skojarzenia» (SJPSzym 39). Takie rozumienie aluzji jest podstawą wyodrębnienia funkcji aluzyjnej nazw własnych, polegającej na przywołaniu za pośrednictwem nazwy określonych skojarzeń i kryjących się za nimi ewentualnych składników konsytuacji aktu nominacyjnego. Aluzja tkwiąca w nazwie może odsyłać zarówno do pewnych zdarzeń, faktów, cech fizycznych, jak i do «otoczenia językowego» aktu nazewniczego - a więc zachowań językowych oraz innych nazw własnych" (Rutkowski 2001: 61).

Wśród denominacji parków linowych w Polsce 34 pełnią funkcję aluzyjną. Większa część tych jednostek onimicznych stanowi aluzję do innych nazw, które zawierają równobrzmiące człony: ABlandia - Krościenko i ABlandia - Rytro, Adrenalina Park i Adrenalina, AdrenaLinaPark Podlesice i AdrenaLinaPark Podzamcze, Geo-Park Glinka i GeoPark Linowy, GIBON Park Linowy oraz trzy parki o nazwie Gibon, cztery obiekty o nazwie $J u$-Huи (jednakowe brzmienie tych 
nazw może utrudniać komunikację), Jumpy Park Malborkstones i Jumpy Park, dwa parki o nazwie Linoskoczek, kolejne dwa nazwane Park Linowy Bluszcz, następne dwa o nazwie Tarzan, dwa o nazwie Tarzania oraz pięć nazwanych TarzanPark.

Ponadto pięć onimów pełni funkcję aluzyjną, przywołując inne elementy konsytuacji. Nazwy Geo-Park Glinka oraz Skalisko odsyłają do dawnych kamieniołomów, na terenie których powstały. Jumpy Park Malborkstones nawiązuje do słynnego zamku w Malborku (choć budowla powstała z cegieł, nie kamieni). Nazwa Park Linowy Chrobry zawiera aluzję do Góry Chrobrego, przy której znajduje się obiekt Ostatnią nazwą pełniącą omawianą funkcję jest Murzasichle - Stary Bór, której aluzyjność może być nieczytelna dla osób spoza regionu, lecz zostaje tu rozpoznana po uwzględnieniu opisu ze strony internetowej parku: „Nazwa Stary Bór nawiązuje do wsi Murzasichle".

\subsection{Relacja nazwa-użytkownik}

W relacji do użytkownika nazwa może pełnić dwie funkcje. Pierwsza — impresywna — zostaje tu przejęta za M. Rutkowskim, który pisze:

Impresywna funkcja nazw własnych polega najogólniej rzecz ujmując na wpływaniu na użytkowników - ujawnia się więc ona w relacji między nazwą a użytkownikiem (odbiorca). Pamiętać tu trzeba o specyfice aktu nominacyjnego, a zwłaszcza o nieobecności odbiorcy, który został wyłączony z konsytuacji [...]. Odbiorca jest wyłącznie użytkownikiem nazw, za pośrednictwem których dokonuje się przekazywanie określonych treści. Wpływanie na użytkownika za pośrednictwem nazwy własnej ma zatem charakter niebezpośredni, uwarunkowany specyfiką odbioru nazwy jako pewnego rodzaju komunikatu językowego. Wpływanie to może polegać na wywoływaniu określonych reakcji użytkowników: rozbawienia, śmiechu, obawy, może też mieć na celu sprowokowanie pewnych postaw — użytkownik może być zachęcony do podjęcia wspinaczki [...] albo odwrotnie (nazwa może go zniechęcić, odstraszyć). [...] Znaczenie leksykalne na usługach funkcji impresywnej ujawnia się w nazwach, w których znaczeniu zawarte są elementy waloryzujące denotat lub odpowiednio nacechowane, mogące wywoływać np. obawę przed daną wspinaczką lub przeciwnie: niwelować strach, zapowiadać wspinaczkę bezpieczną, przyjemną, piękną (2001: 97-98).

Ze względu na specyfikę badanego materiału w nazewnictwie parków linowych - wewnattrz funkcji impresywnej — zostaje jednak wydzielona funkcja humorystyczna, która będzie omówiona osobno.

Pozytywną reakcję osoby mającej kontakt z parkami linowymi może wywołać 40 onimów. Większość spośród nich zachęca do wspinaczki w obiektach, które denotują, zapowiadając przygodę, zabawę czy wzrost poziomu adrenaliny: Adrenalina Park, Adrenalina, AdrenaLinaPark Podlesice, AdrenaLinaPark Podzamcze, Afor Adventure Park, AndersLand, Fabryka Wrażeń, Fabryka Przygody, Fastpark,

7 Nazwa ta nie została zaklasyfikowana jako pełniąca funkcję aluzyjną również do pierwszego króla Polski, gdyż zawiera nazwisko osoby, od której nazwano górę w mianowniku.

8 Strona internetowa parku: http://www.starybor.pl (dostęp 6 IX 2016). 
Fun Park, FUN-Linopark, FunForce, Mamruch, Mountain Emotion, Park Linowy „4FUN”, Park Linowy Funtour, Park Linowy Góra Harców, Park Linowy Las Przygód, Park Linowy Leśna Przygoda, Park Linowy „Leśny Raj”, Park Przygody Balaton, Park Przygody Nad Pilica, Podstolice Ski \& Adventure, Przygoda Park, Rodzinny Park Rozrywki ,,Trzy Wzgórza”, Wyspa Przygody Opatowiecka. Kolejne cztery nazwy: Park Linowy Radocha, Park Rekreacji Zoom Natury, Piękna Góra Rudziewicz i Wypasiona Dolina. Koncentrują one uwagę odbiorcy na cechach niekoniecznie związanych ze wzrostem poziomu adrenaliny, a ogólnie uznawanych za pozytywne, takich jak piękno czy radość. Z kolei nazwa Veni Vici zakłada powodzenie w pokonaniu tras, a onim $J u$-Huu, odczytany jako okrzyk w trakcie zjazdów tyrolkami, sugeruje, że sprawiają one raczej przyjemność, niż trwożą. Ostatnich sześć nazw zachęca do skorzystania z parku te osoby, które szukają najmocniejszych wrażeń, te, dla których standardowe trasy nie stanowią wyzwania: Cascader Park, High-Position, Park Linowy Hardcore, Wake Park Solina, Xtremepark, Inowrocław Centrum Extreme.

Wśród badanych nazw znajdują się również propria zawierające apelatywy negatywnie nacechowane. Wydaje się jednak, że i one zachęcają do skorzystania z denotowanych przez siebie obiektów; jest w nich specyficzna przekora, prowokacja, skłaniająca do zmierzenia się z przeszkodami lub ostrzeżenie przed niebezpieczeństwem. Nazwy te zatem są pozornie negatywnie nacechowane: oparte wprawdzie na pejoratywnie zabarwionych leksemach, ale ich funkcją jest mobilizacja potencjalnych użytkowników parków do skorzystania z nich, rzucone im wyzwanie.

Do tej grupy denominacji zostały zaliczone: Granda (granda 'wielka awantura'9), Kamikaze (kamikaze 'osoba porywająca się na działania bardzo ryzykowne, niemające szans powodzenia' ${ }^{10}$ ), Ranczo Furia West (furia 'nagły, silny napad wściekłości' ${ }^{11}$ ) oraz Sparta Adwenture Park (Sparta 'państwo wojowników', spartańskie wychowanie 'wychowanie surowe, bezwzględne' (Rutkowski 2012: 108)).

Drugą funkcją, jaką nazwa parku linowego może pełnić wobec użytkownika, jest funkcja humorystyczna. Pojawia się wtedy, gdy nazwa wywołuje śmiech czy rozbawienie. Funkcja ta została tu zbadana z wykorzystaniem współczesnej dla badań humoru teorii niespójności (Rutkowski 2006: 398). Za M. Rutkowskim przejęto pięć grup nazw humorystycznych: nomina propria o podstawowym rodzaju niespójności nieznaczące-znaczące; onimy z tym samym typem niespójności pojawiające się w sytuacjach wzmacniających prawdopodobieństwo rozśmieszenia (nazwanych „katalizatorem” (Lew 2000: 131); nazwy z rodzajem niespójności neutralne-nacechowane (które można zaklasyfikować jako kolokwialne, wulgarne czy należące do określonych pól semantycznych, takich jak fizjologia czy skatologia); onimy, które

\footnotetext{
${ }^{9}$ http://sjp.pwn.pl/szukaj/granda.html (dostęp 16 IX 2016).

${ }^{10} \mathrm{http}: / /$ sjp.pwn.pl/szukaj/kamikaze\%20.html (dostęp 16 IX 2016).

${ }^{11}$ http://sjp.pwn.pl/szukaj/furia\%20.html (dostęp 16 IX 2016).
} 
deprecjonują swoje denotaty oraz ,niedopasowane” lub „dopasowane” zgrupowania nazw (por. Rutkowski 2006: 400-403).

Ze względu na rodzaj obiektów, które denotują, użycie apelatywów jako (fragmentów) nazw parków linowych nie musi wywołać żadnych reakcji użytkownika, w tym rozbawienia. W czterech pozostałych grupach onimów humorystycznych nazw parków linowych odnajdziemy natomiast w jednej jednostki onimiczne z katalizatorem. Kategoria ta jest bardzo liczna, zawiera 25 denominacji. We wszystkich przypadkach katalizatorem jest rodzaj nazwanego obiektu, jego fragment lub przeznaczenie. Pięć onimów: Fabryka Matp, Matpi Gaj, Małpi Jar, Szklarska Poręba Trollandia oraz Żar Trollandia jest niespójnych z gatunkiem istot, dla których parki linowe są przeznaczone. Nazwa Kamikaze stoi w opozycji do przeżycia, które jest niezbędnym elementem zabawy w parku linowym. Niespójność z rodzajem denotowanego obiektu wykazuje nazwa Leśny Tabor, natomiast z elementami obiektu niespójne są następujące nomina propria: Jumpy Park Malborkstones (drzewa vs kamienie), Sherwood (polski las vs las angielski), Veni Vici (nie można zobaczyć trasy przed jej zdobyciem), Gekon (poruszanie się po ziemi vs pomiędzy drzewami) oraz Gibon (pewne przejście vs gibanie się na przeszkodach lub po spadnięciu $\mathrm{z}$ nich) ${ }^{12}$. Przeznaczenie — aktywna zabawa — jest z kolei niespójne z elementami następujących nazw: Park Linowy Klub Piknikowy, Park Linowy Malutkie Resort (resort 'miejsce, do którego ludzie udają się na wakacje'13), Ranczo Furia West, Park Linowy Pohulanka, Granda, Hotel Remes, Park Linowy Kapielisko Chorwacja (zabawa w wodzie vs zabawa na linach), Park Przygody „,Nowa Makumba”, Podniebny Cyrk oraz Sabat Krajno.

Poza wyodrębnionymi w przyjętym podziale grupami znalazły się nazwy, w których niespójność ma charakter językowy. Jest to zaburzenie w syntaksie: Lina Adrena oraz połączenie w nazwie dwóch języków: Base Camp Istebna, Park Linowy „,4FUN”, Park Linowy Funtour, Park Linowy Spiker, Podstolice Ski \& Adventure, Park Rekreacji Zoom Natury, Sparta Adwenture Park, Wake Park Solina.

\section{PODSUMOWANIE}

Powyższa analiza wykazała, że tylko 24 nazwy parków linowych w Polsce nie pełnią żadnej funkcji sekundarnej — liczba ta obejmuje jedynie 10,5\% wszystkich zbadanych onimów. Najwięcej zanalizowanych jednostek onimicznych pełni funkcję lokalizacyjną (98 nazw) oraz deskrypcyjną (79 nazw), najmniej licznie re-

12 Onim ten może również kojarzyć się z gibonem — zwierzęciem sprawnie poruszającym się wśród konarów drzew, co nie powoduje pojawienia się niespójności. Ze względu na specyfikę niektórych przeszkód zaprojektowanych tak, aby wywołać kołysanie, możliwe jest jednak skojarzenie z czasownikiem gibać się.

13 http://www.oxfordlearnersdictionaries.com/definition/english/resort_1?q=resort (dostęp 30 V 2017). 
alizowane są funkcje: poetycka (12 nazw) oraz ekspresywna (12 nazw). Prowadzi to do wniosku, że najistotniejsze dla twórców nazw było określenie lokalizacji i opis nazywanych przez nich parków, a najmniej ważne — zwrócenie uwagi użytkownika na samą nazwę oraz wyrażanie własnych emocji. Produktywną jednostką leksykalną w opisie parków okazało się imię najsłynniejszej postaci ludzkiej przemieszczającej się pomiędzy drzewami - Tarzana. Inne nazwy deskrypcyjne nawiązują najczęściej do czynności wykonywanych w parkach linowych, do poziomu ich trudności oraz do cech parków. Nazwy lokalizujące obiekty najcześsiej wskazują na miejscowość, w której położony jest park. Większość jednostek pełniących funkcję aluzyjną zawiera wyrażenie „park linowy” na początku onimu, żeby odróżnić ten obiekt od większego kompleksu, na terenie którego się znajduje i do którego nazwy nawiązuje.

Narzędzia zaproponowane przez M. Rutkowskiego do analizy funkcji mikrotoponimów przestrzeni wspinaczkowej okazały się odpowiednie do przeprowadzenia studium nazw parków linowych w Polsce. Nieliczne zmiany wprowadzone w tej pracy do typologii Rutkowskiego są spowodowane różnicami pomiędzy charakterem badanych obiektów.

Wyniki przedstawionego studium mogą też zostać wykorzystane jako punkt odniesienia dla analiz porównawczych funkcji nazw własnych parków linowych w Polsce i innych krajach. Być może warte zbadania są również nazwy poszczególnych tras oferowanych w tych parkach.

\section{LITERATURA}

Gruchmanowa M., Walczak B. (red.) 1997: Stownik gwary miejskiej Poznania, PWN, Warszawa.

Handke R. 1993: Styl artystyczny, [w:] J. Bartmiński (red.), Współczesny język polski. „Encyklopedia Kultury Polskiej XX w." 2, Wiedza o Kulturze, Wrocław, s. 135-145.

Lew R. 2000: Dowcip językowy w świetle najnowszych językoznawczych teorii humoru, [w:] S. Gajda,

D. Brzozowska (red.), Świat humoru, Wyd. UOp, Opole, s. 127-135.

Rutkowski M. 2001: Mikrotoponimia przestrzeni wspinaczkowej. Studium socjoonomastyczne, Wyd. UWM, Olsztyn.

Rutkowski M. 2006: Humor w nazwach własnych, [w:] K. Rymut i in. (red.), Munuscula linguistica in honorem Alexandrae Cieślikowa oblata, Wyd. IJP PAN, Kraków, s. 397-409.

Rutkowski M. 2012: Stownik metafor i konotacji nazw własnych, Instytut Filologii Polskiej. UWM, Olsztyn.

SJPSzym — Szymczak M. (red.) 1994: Stownik języka polskiego, t. I, PWN, Warszawa.

Sychta B. 1972: Stownik gwar kaszubskich, t. V, Ossolineum, Wrocław.

http://polskieparkilinowe.pl/

http://sjp.pwn.pl/

http://www.oxfordlearnersdictionaries.com/

http://www.starybor.pl

http://www.veni-vici.com.pl/dlaczego.php 


\section{FUNCTIONS OF PROPER NAMES OF ROPES COURSES IN POLAND}

\section{SUMMARY}

Ropes courses are places where for a brief period of time one can find oneself among the treetops and confront one's fear of heights. Having originated in France, this form of activity is becoming increasingly popular in Poland; however, its onomastic stratum has not been examined yet. Therefore, the main aim of this article is to analyse the functions served by the names of ropes courses in Poland. Basing the research on the methodology proposed by Mariusz Rutkowski in his study of microtoponymy of climbing space, I will concentrate on the secondary functions of about two hundred proper names of ropes courses in Poland.

Ke y w ord s: onomastics, microtoponymy, functions of proper names 